\title{
Chromosomal distribution of the As51 satellite DNA in two species complexes of the genus Astyanax (Pisces, Characidae)
}

\author{
Luciano Douglas dos Santos Abel, Monique Mantovani and Orlando Moreira-Filho \\ Departamento de Genética e Evolução, Universidade Federal de São Carlos, São Carlos, SP, Brazil.
}

\begin{abstract}
The chromosomal localization of the As51 satellite DNA was identified by fluorescent in situ hybridization (FISH) in specimens of the characid fish Astyanax scabripinnis and Astyanax fasciatus, which are considered species complexes because of their extensive karyotypical and morphological variability. A conserved chromosomal distribution of the As51 satellite, coincident with distal C-banded segments was demonstrated. The alternative interstitial localization of this satellite DNA and possible alterations of its structure suggest that this sequence underwent quantitative, positional and structural variations, as the $A$. scabripinnis and $A$. fasciatus complexes diverged.
\end{abstract}

Key words: As51, Astyanax scabripinnis, Astyanax fasciatus, fluorescence in situ hybridization (FISH), C-banding, satellite DNA.

Received: January 26, 2005; Accepted: October 10, 2005.

\section{Introduction}

A large portion of the genome of eukaryotes consists of repetitive sequences, which are dispersed or organized in tandem (Charlesworth et al., 1994). Tandemly organized repetitive DNA is known as satellite DNA and is normally located in heterochromatic regions detectable by Cbanding (Brutlag, 1980; Sumner, 1990). In fish, satellite DNAs co-localize with centromeric and pericentromeric heterochromatin (Haaf et al., 1993; Oliveira and Wright, 1998; Phillips and Reed, 2000; Jesus et al., 2003).

Astyanax scabripinnis and Astyanax fasciatus are taxonomic entities of the freshwater Neotropical ichthyofauna, and their morphological and karyotypic characteristics indicate that they are species complexes (MoreiraFilho and Bertollo, 1991; Centofante et al., 2003; Pazza et al., 2006). In this context, the extensive interpopulational variation in localization and amount of C-bands allowed the characterization of distinct populations of both the scabripinnis and the fasciatus complexes (Moreira-Filho and Bertollo, 1991; Souza and Moreira-Filho, 1995; Souza et al., 1995; Maistro et al., 1998; Mizoguchi and Martins-Santos, 1998; Mantovani et al., 2000; Pazza et al., 2006).

In their study of $A$. scabripinnis from the Rio Grande River Basin in southeastern Brazil, Mestriner et al. (2000) identified a 59\% AT-rich satellite DNA family with mono-

Send correspondence to Orlando Moreira-Filho. Departamento de Genética e Evolução, Universidade Federal de São Carlos, Rodovia Washington Luís km 235, Caixa Postal 676, 13565-905 São Carlos, SP, Brazil. E-mail: omfilho@ power.ufscar.br. meric units of $51 \mathrm{bp}$, called As51, and determined its chromosomal distribution. These authors showed, by Southern blot hybridization, that As51 was also present in other $A$. scabripinnis populations. This satellite DNA was also detected in A. fasciatus, but not in A. altiparanal and $A$. schubarti (C.A. Mestriner, personal communication). In this work we analyzed the chromosomal distribution of the As51 satellite DNA in the scabripinnis complex. The chromosomal localization of this repetitive DNA was determined in specimens from four populations of this species complex and in a sample of $A$. fasciatus, for comparative analysis.

\section{Materials and Methods}

\section{Specimens, chromosome preparations and C-banding}

Specimens were collected from five distinct waterways in three river basins in southeastern Brazil (Table 1). Mitotic chromosomes were obtained as described by Bertollo et al. (1978), and C-banding was performed according to Sumner (1972).

\section{FISH procedures}

We used as probe the As51 satellite DNA sequence inserted in a Promega pGEM4 plasmid (Mestriner et al., 2000) labeled with biotin-14-dATP by nick translation, using the BioNick ${ }^{\mathrm{TM}}$ Labeling System (Gibco BRL), according to the manufacturer's instructions. FISH was carried out according to Pinkel et al. (1986), with some modifications. Chromosome preparations were pretreated with 
Table 1 - Collection sites and number of specimens of Astyanax analyzed.

\begin{tabular}{|c|c|c|c|c|c|c|}
\hline Species & Waterway & River Basin & Location & $\mathrm{F}$ & M & $2 n$ \\
\hline A. scabripinnis & Centenário Stream & Paranapanema River & Maringá/Paraná State & 4 & 4 & 50 \\
\hline A. scabripinnis & Marrecas Stream & Paranapanema River & Londrina/Paraná State & 7 & 3 & 48 \\
\hline A. scabripinnis & Viveiro de Mudas Stream & São Francisco River & Três Marias/Minas Gerais State & 7 & 4 & 50 \\
\hline A. scabripinnis & Curral das Éguas Stream & São Francisco River & São Gonçalo do Abaeté/Minas Gerais State & 3 & 2 & 46 \\
\hline A. fasciatus & Piracicaba River & Tietê River & Piracicaba/São Paulo State & 3 & 4 & 46 \\
\hline
\end{tabular}

$\mathrm{F}=$ females; $\mathrm{M}=$ males; $2 \mathrm{n}=$ diploid number.

RNAse $(40 \mu \mathrm{g} / \mathrm{mL}$ in $2 \mathrm{xSSC})$ in a moist chamber at $37^{\circ} \mathrm{C}$ for one hour, followed by dehydration in an alcohol series. Chromosome denaturation was performed with $70 \%$ formamide in $2 \mathrm{xSSC}$ at $70{ }^{\circ} \mathrm{C}$ for $5 \mathrm{~min}$. The hybridization solution [ $50 \%$ formamide, $10 \%$ dextran sulfate, $2 \times$ SSC and $1 \mu \mathrm{L}$ of human placenta DNA $(10 \mathrm{mg} / \mathrm{mL})]$ containing approximately $125 \eta \mathrm{g}$ of the probe, was kept in boiling water for $10 \mathrm{~min}$, and then $50 \mu \mathrm{L}$ were placed on each slide and covered with a coverslip. Hybridization was performed in a moist chamber containing $60 \%$ formamide for $15 \mathrm{~h}$ at $37^{\circ} \mathrm{C}$. Then, the slides were rinsed with $50 \%$ formamide in $2 \mathrm{xSSC}$ at $42{ }^{\circ} \mathrm{C}$ for $20 \mathrm{~min}$ and with $0.1 \mathrm{xSSC}$ at $60^{\circ} \mathrm{C}$ for $15 \mathrm{~min}$. Probe detection was carried out with avidin-FITC (fluorescein isothiocyanate) conjugate, biotinylated antiavidin (Sigma), and avidin-FITC conjugate. The slides were mounted with $25 \mu \mathrm{L}$ of Vectashield antifade (Vector), and the chromosomes stained with $1 \mu \mathrm{L}$ of propidium iodide $(50 \mu \mathrm{g} / \mathrm{mL})$. Metaphase chromosomes were examined under an Olympus BX50 fluorescence microscope and photographed with Kodak Gold Ultra 400 ISO film.

\section{Results}

In A. scabripinnis specimens from the Centenário and Marrecas streams (in the Paranapanema River Basin), As51 satellite DNA was detected by FISH at the ends of the long arms of most subtelocentric and acrocentric chromosomes and of one submetacentric pair, thus corresponding to the non-perincentromeric C-bands (Figure 1).

The A. scabripinnis specimens from the Viveiro de Mudas stream showed interindividual numerical variation of the FISH signals observed at the end of the long arm of an acrocentric pair, as well as of the small subterminal signals on the long arms of some subtelocentric and acrocentric chromosomes (Figures 2a, 2b and 2c). C-bands were present in the pericentromeric regions of all chromosomes; small C-banded distal segments were also detected on several pairs of chromosomes, but showed interindividual numerical variation (Figure 2e). The FISH signals of the As51 satellite probe co-localized with the distal $\mathrm{C}$-bands on the long arms of the acrocentric pair, but not with other C-bands.

The As51 satellite probe did not yield signals on the chromosomes of $A$. scabripinnis specimens from the Curral das Éguas stream (Figure 2d). C-bands were pericentromeric or appeared as distal blocks (Figure 2f).

In A. fasciatus from the Piracicaba River, the As51 sequence was detected on the ends of the long arms of the subtelocentric (except for pair 17) and acrocentric chromosomes and of the submetacentric pair 11 (Figure 3a). These FISH signals corresponded to C-bands (Figure 3b). No hybridization signals co-localized with the pericentromeric C-bands or with the distal C-band of chromosome pair 8.

\section{Discussion}

In the A. scabripinnis population from which it was isolated (Córrego das Pedras stream), the As51 satellite DNA was located on the supernumerary chromosome, on the terminal C-bands of the long arms of some acrocentric chromosomes of the A complement and associated with the nucleolar organizer regions (Mestriner et al., 2000). This chromosomal distribution and those reported here, show that this sequence has a variable localization among $A$. scabripinnis populations. It may even be absent, at least at the level of FISH detection, as in the specimens from the Curral das Éguas stream. However, within this variability, the specimens from the Paranapanema River Basin presented the same chromosomal distribution of the satellite As51, which co-localizes with the C-band blocks on the distal long arms of subtelocentric and acrocentric chromosomes. These populations were shown to share some conserved karyotype characteristics within the scabripinnis complex (Mantovani et al., 2000), and our data adds a new-shared character. It is noteworthy that the chromosomal localization of the As51 satellite DNA observed in $A$. scabripinnis from the Paranapanema River Basin is very similar to that of $A$. fasciatus.

The A. scabripinnis specimens from the Viveiro de Mudas (our data) and Córrego das Pedras (Mestriner et al. 2000) streams present fewer acrocentric chromosomes bearing As51 satellite DNA at the ends of the long arms. Therefore, gain or loss of this satellite DNA must have occurred during the differentiation of the populations of the Paranapanema and São Francisco River Basins. Furthermore, unlike the A. scabripinnis specimens from the Paranapanema River Basin, in which every nonpericentromeric C-banded segment bears the As51 family, the $A$. scabripinnis specimens from the São Francisco River Ba- 

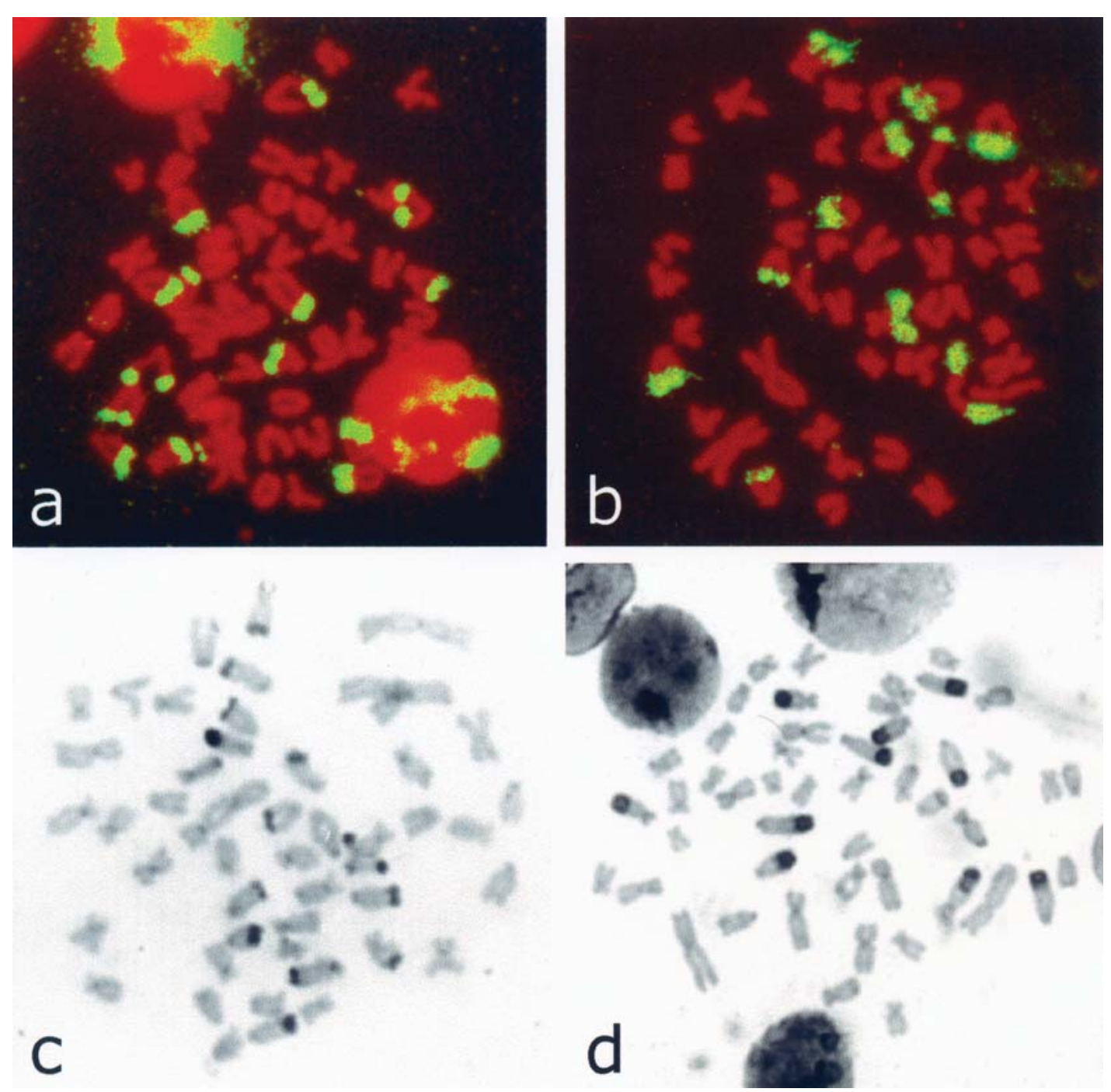

Figure 1 - Chromosomal distribution of As51 satellite DNA after FISH, in specimens of $A$. scabripinnis from the Centenário (a) and Marrecas (b) streams. C-banding pattern in A. scabripinnis specimens from the Centenário (c) and Marrecas (d) streams.

sin show distal C-bands which are not coincident with the FISH signals. This is also the case of the short arm of chromosome pair 8 of the $A$. fasciatus specimens analyzed here. These findings indicate that $\mathrm{C}$-band sequences other than the As51 satellite evolved during the diversification of the A. scabripinnis and A. fasciatus complexes, possibly occupying distinct chromosome territories and being subject to chromosomal dispersion patterns different from those of the As51 satellite.

The interstitial localization of the As51 satellite DNA on some chromosomes of the specimens from the Viveiro de Mudas stream suggests that in this population it probably may have followed an evolutionary path different from that in of the distal segments of acrocentric chromosomes. Mestriner et al. (2000) showed that the molecular organization of this sequence is similar to that of mobile elements, suggesting that it may have been transferred to the $45 \mathrm{~S}$ rDNA spacers of the Córrego das Pedras A. scabripinnis population. Analogously, transferences of the As51 family may have caused it to reach the aforementioned interstitial position and to lose its $\mathrm{C}$-band nature, probably as a result of changes in its structural conformation and in the structural chromosomal proteins associated to it.

Based on positive or negative staining by the basespecific fluorochromes mithramycin A and DAPI, Mantovani et al. (2004) concluded that the C-band blocks that we showed to be coincident with the As51 satellite DNA localization in A. scabripinnis from the Centenário and Marrecas streams possess a different structural organization. These blocks may also differ from those of the Viveiro de Mudas specimens which hybridized with the As51 satellite probe, but were not stained by the basespecific fluorochromes chromomycin A3 and DAPI (our unpublished data). These observations demonstrate that C-banded segments containing As51 satellite might differ structurally. 

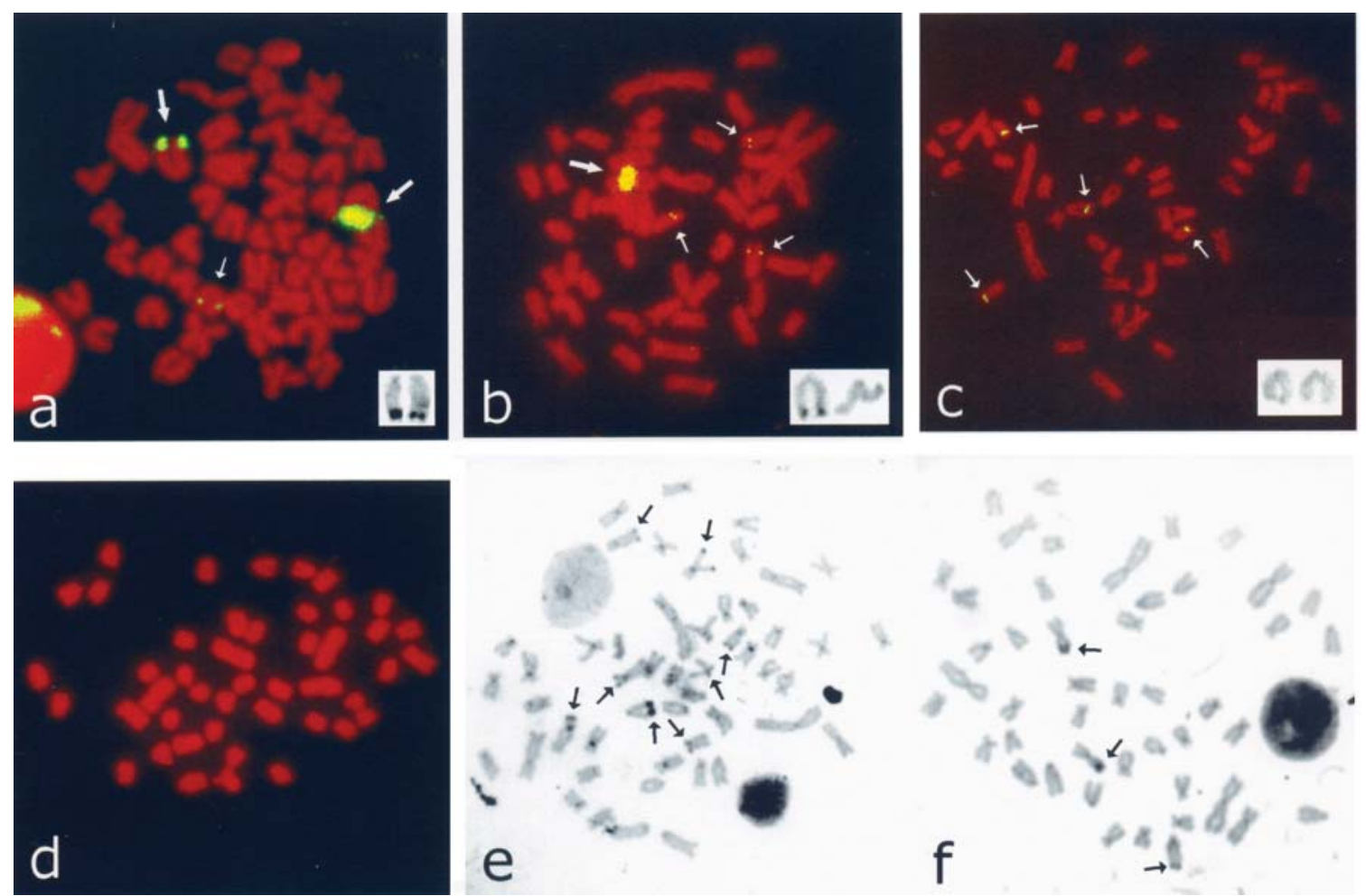

Figure 2 - Chromosomal distribution of FISH signals of As51 satellite DNA in three A. scabripinnis individuals from the Viveiro de Mudas stream (a, b and c). Large arrows indicate terminal blocks and small arrows indicate small subterminal signals. The acrocentric chromosomes bearing C-band distal blocks are shown in the inserts. No As51-FISH signals were observed on the chromosomes of A. scabripinnis from the Curral das Éguas stream (d). C-banded metaphases from A. scabripinnis specimens collected in the Viveiro de Mudas (e) and Curral das Éguas (f) streams (some C-bands are indicated by arrows).
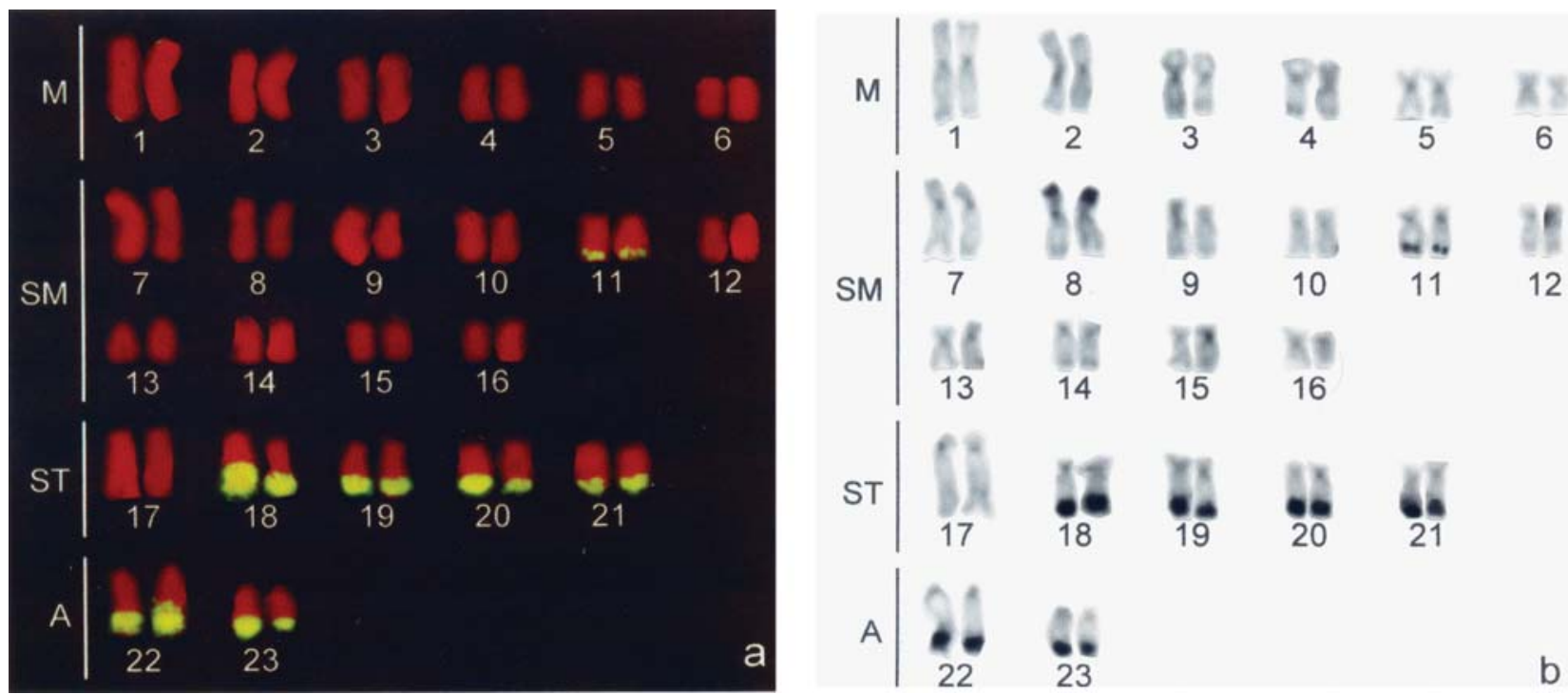

Figure 3 - Chromosomal distribution of As51 satellite DNA after FISH (a), and C-banding (b) in A. fasciatus from the Piracicaba River.

The diversification of the As51 satellite DNA in $A$. scabripinnis, in terms of quantity, positioning and structural conformation, reinforces the assumption that this group is a species complex (Moreira-Filho and Bertollo, 1991).

It is well known that heterochromatin can rearrange nuclear architecture and thus interfere in gene activity, de- pending on the localization effect of heterochromatin blocks on adjacent or distant genes (Henikoff, 1990; Zuckerkandl and Hennig, 1995). Future studies evaluating how the location of the As51 satellite DNA affects molecular, morphological and ecological variants would complement our discussion on the evolution of the As51 satellite DNA in the scabripinnis and fasciatus species complexes. 


\section{Acknowledgements}

The authors thank Horácio Ferreira Júlio Jr., Lúcia Giuliano-Caetano and Yoshimi Sato for their help in collecting the specimens analyzed here. This work was supported by Fundação de Amparo à Pesquisa do Estado de São Paulo (FAPESP, 98/07193-7 and 98/07187-7) and by Companhia do Desenvolvimento do Vale do São Francisco (CODEVASF).

\section{References}

Bertollo LAC, Takahashi CS and Moreira-Filho O (1978) Cytotaxonomic considerations on Hoplias lacerdae (Pisces, Erythrinidae). Rev Bras Genet 1:103-120.

Brutlag DL (1980) Molecular arrangment and evolution of heterochromatic DNA. Annu Rev Genet 14:121-144.

Centofante L, Bertollo LAC, Justi AJ and Moreira-Filho O (2003). Correlation of chromosomal and morphologic characters in two Astyanax species (Teleostei, Characidae). Ichthyo Explor Freshwaters 14:361-368.

Charlesworth B, Sniegowski P and Stephan W (1994) The evolutionary dynamics of repetitive DNA in eukaryotes. Nature 371:215-220.

Haaf T, Schmid M, Steinlein C, Galetti Jr. PM and Willard HF (1993) Organization and molecular cytogenetics of satellite DNA family from Hoplias malabaricus (Pisces, Erythrinidae). Chromosome Res 1:77-86.

Henikoff S (1990) Position-effect variegation after 60 years. Trends Genet 6:422-426.

Jesus CM, Galetti Jr. PM, Valentini SR and Moreira-Filho O (2003) Molecular characterization and chromosomal localization of two families of satellite DNA in Prochilodus lineatus (Pisces, Prochilodontidae), a species with B chromosomes. Genetica 118:25-32.

Maistro EL, Oliveira C and Foresti F (1998) Comparative cytogenetic and morphological analysis of Astyanax scabripinnis paranae (Pisces, Characidae, Tetragonopterinae). Genet Mol Biol 21:201-206.

Mantovani M, Abel LDS, Mestriner CA and Moreira-Filho O (2004) Evidence of the differentiated structural arrangement of constitutive heterochromatin between two populations of Astyanax scabripinnis (Pisces, Characidae). Genet Mol Biol 27:536-542.

Mantovani M, Abel LDS, Mestriner CA and Moreira-Filho O (2000) Accentuated polymorphism of heterochromatin and nuclear organizer regions in Astyanax scabripinnis (Pisces, Characidae): Tools for understanding karyotypic evolution. Genetica 109:161-168.

Mestriner CA, Galetti Jr. PM, Valentini SR, Ruiz IRG, Abel LDS, Moreira-Filho O and Camacho JPM (2000) Structural and functional evidence that a $\mathrm{B}$ chromosome in the characid fish Astyanax scabripinnis is an isochromosome. Heredity 85:1-9.

Mizoguchi SMHN and Martins-Santos IC (1998) Cytogenetic and morphometric differences in populations of Astyanax scabripinnis (Pisces, Characidae) from Maringá region, PR, Brazil. Genet Mol Biol 21:55-61.

Moreira-Filho O and Bertollo LAC (1991) Astyanax scabripinnis (Pisces, Characidae): A species complex. Brazil J Genet 14:331-357.

Oliveira C and Wright JM (1998) Molecular cytogenetic analysis of heterochromatin in the chromosomes of tilapia, Oreochromis niloticus (Teleostei, Cichlidae). Chromosome Res 6:205-211.

Pazza R, Kavalco KF and Bertollo LAC (2006) Chromosome polymorphism in Astyanax fasciatus (Teleostei, Characidae). 1. Karyotype analysis, Ag-NORs and mapping of the $18 \mathrm{~S}$ and $5 \mathrm{~S}$ ribosomal genes in sympatric karyotypes and their possible hybrid forms. Cytogenet Genome Res 112:313-319.

Phillips RB and Reed KM (2000) Localization of repetitive DNAs to zebrafish (Danio rerio) chromosomes by fluorescence in situ hybridization (FISH). Chromosome Res 8:27-35.

Pinkel D, Straume T and Gray JW (1986) Cytogenetic analysis using quantitative, high-sensitivity, fluorescence hybridization. Proc Natl Acad Sci USA 83:2934-2938.

Souza IL and Moreira-Filho O (1995) Cytogenetic diversity in the Astyanax scabripinnis species complex (Pisces, Characidae). I. Allopatric distribution in a small stream. Cytologia 60:1-11.

Souza IL, Moreira-Filho O and Bertollo LAC (1995). Cytogenetic diversity in the Astyanax scabripinnis species complex (Pisces, Characidae). II. Different cytotypes living in sympatry. Cytologia 60:273-281.

Sumner AT (1972) A simple technique for demonstrating centromeric heterochromatin. Exp Cell Res 75:304-306.

Sumner AT (1990) Chromosome Banding. Academic Division of Unwin Hyman, London, 434 pp.

Zuckerkandl E and Hennig W (1995) Tracking heterochromatin. Chromosoma 104:75-83.

Associate Editor: Fausto Foresti 